\title{
Dietary glutamine enhances immune responses of dairy cows under high ambient temperature
}

\author{
M. Caroprese, ${ }^{1}$ M. Albenzio, R. Marino, A. Santillo, and A. Sevi \\ Department of the Sciences of Agriculture, Food and Environment, University of Foggia, Via Napoli, 25, 71122 Foggia, Italy
}

\begin{abstract}
The objective of the study was to determine the effects of adding Gln or Gln in combination with flaxseed to the diet on milk production and immune response of dairy cows during the summer season. The experiment lasted $60 \mathrm{~d}$ and involved 24 lactating Friesian cows, divided into 4 groups of 6 animals, fed as follows: (1) control diet, (2) control diet supplemented with $160 \mathrm{~g} / \mathrm{d}$ of rumen-protected Gln (GLN), (3) control diet supplemented with whole flaxseed (FS), and (4) control diet supplemented with both flaxseed and Gln (FS+GLN). Individual milk samples were collected at morning and afternoon milkings every $14 \mathrm{~d}$ throughout the experiment and analyzed for $\mathrm{pH}$, total protein, casein, fat, lactose content, and somatic cell count. Milk samples were also analyzed for milk fatty acid profile. Monitoring of cow immune responses was carried out by the determination of lymphocyte response to phytohemagglutinin in vivo on each animal by measurement of skin-fold thickness at site of phytohemagglutinin injection. A humoral response to chicken egg albumin (OVA) was determined following a subcutaneous injection with OVA. Plasma samples were measured for the presence of anti-OVA IgG, IL-1 $\beta$, IL-6, and IL-10. Results indicate that Gln administration can be used to support dairy cows under a hot climate, because Gln was able to enhance cow immune reactions in terms of a strengthening of cell-mediated immune response, which is weakened in cows under heat stress. In addition, an increase in milk and fat, protein, and casein yields in response to GLN was observed. When administrating Gln in combination with flaxseed, milk production and milk fat profile did not further increase compared with FS milk, and a reduction in immune reactivity compared with FS and GLN cows was found.
\end{abstract}

Key words: flaxseed, glutamine, immune response, high ambient temperature

Received October 24, 2012.

Accepted January 21, 2013

${ }^{1}$ Corresponding author: m.caroprese@unifg.it

\section{INTRODUCTION}

High ambient temperature, especially when associated with high relative humidity, alters metabolism and hormonal secretions of dairy cows, along with a reduction in feed intake and milk production (West, 1999). The drop in milk production is the outcome of a reduction in nutrient intake and in nutrient uptake by the mammary gland, and of a change in nutrient partitioning to regulate thermal balance (West, 2003). Several feeding strategies have been proposed for the maintenance of milk production in heat-stressed cows by improving the energy efficiency and reducing heat production. The use of conjugated linoleic acids (CLA) in the diet of cows under a hot environment has been studied as a means to moderate negative responses to heat stress, but it resulted in milk fat depression (Moore et al., 2005; Liu et al., 2008). Whole flaxseed added to the diet of dairy cows during the summer was shown to increase milk production and improve milk quality in terms of fat content and FA composition beneficial to human health (Caroprese et al., 2010). Besides modifications of the diet, including fat supplementation, the optimization of protein content of diet has been recommended as a nutritional strategy for heat-stressed cows (West, 1999). West (1999) suggested that the profile of AA delivered plays an important role in the diet of heat-stressed cows. When testing different levels of rumen-protected Gln on cow milk production during mid lactation, Caroprese et al. (2012) found a moderate increase in milk yield and an increase in Glu, Pro, Asp, Val, and total essential AA in the AA profile of milk.

In addition to the reduction of milk production, dairy cows under a hot environment suffer from a reduction of immune competence, which is caused by the alterations of the circulating hormones and by the need to control thermoregulatory mechanisms. The consequent reduction of cell-mediated immune responses can be overcome by the utilization of whole flaxseed, which has been found to be effective in increasing alerted T-lymphocyte responses (Caroprese et al., 2009). Different stressors, such as feed deprivation, exercise, malnutrition, or illness, decrease plasma concentrations of free Gln in ruminants (Meijer et al., 1995). Glutamine administration to dairy cows was able to exert a modu- 
lation of cow immune responses in the absence of acting stressors (Caroprese et al., 2012). Moreover, Gln availability is needed for rat, mouse, and human in vitro proliferative responses of T-lymphocyte to mitogens, and Gln utilization increases in cases of lymphocyte activations (Yaqoob and Calder, 1998).

This study, therefore, was undertaken to evaluate the effects of dietary Gln in dairy cows under high ambient temperature, administered alone or in combination with flaxseed, on milk production and composition, and immune functions.

\section{MATERIALS AND METHODS}

\section{Animals and Monitoring of Environmental Conditions}

The experimental site was a commercial farm located approximately $20 \mathrm{~km}$ northeast of Foggia, Apulia, Italy (latitude: $41^{\circ} 27^{\prime} 6^{\prime \prime}$; longitude: $15^{\circ} 33^{\prime} 5^{\prime \prime}$ ). Air temperature and the relative humidity were monitored daily using TIG2-TH thermo-hygrographs (LSI, Settala Premenugo, Milan, Italy). Data from thermo-hygrographs in conjunction with Kelly and Bond's formula (Kelly and Bond, 1971) were used to calculate the temperature-humidity index (THI). The experiment lasted $60 \mathrm{~d}$ and was performed from May to July of 2007 on 24 Italian Friesian cows, divided into 4 groups of 6 each, which were balanced according to age, BW, DIM $(108.33 \pm 4.13$; mean $\pm \mathrm{SD})$, parity $(2.79 \pm 0.07)$, milk yield $(22.46 \pm 0.48 \mathrm{~kg} / \mathrm{d})$, milk fat $(3.50 \pm 0.08)$, and protein content $(3.50 \pm 0.23)$. Prior to and during the experiment, all cows were assessed by veterinarians to exclude the presence of signs of clinical mastitis (pain, gland swelling, fever). A small quantity of milk was checked visually for signs of mastitis (flakes, clots, or blood); no cases of mastitis were detected during the study period.

\section{Experimental Diets and Chromatographic Analysis of Feed}

All animals were housed in tiestalls and individually fed the dietary treatments as follows: (1) control diet (C) containing corn, oat hay, and concentrate; (2) control diet supplemented with $400 \mathrm{~g} / \mathrm{d}$ rumen-protected L-Gln 40\% (Ascor Chimici, Capocolle di Bertinoro, Italy) providing $160 \mathrm{~g} / \mathrm{d}$ rumen-protected Gln (GLN); (3) a diet containing $1.2 \mathrm{~kg} / \mathrm{d}$ of whole flaxseed (FS) in substitution of an equal amount of concentrate of the control diet (Lin Tech, Tecnozoo srl, Torreselle di Piombino Dese, Italy), as reported in Caroprese et al. (2009, 2010); and (4) control diet supplemented with rumen-protected Gln and whole flaxseed (FS+GLN). The diet was fed twice daily (0600 and $1400 \mathrm{~h}$ ) as a TMR, and feed intake was recorded daily. Diet composition is shown in Table 1.

The amount of the daily ration offered the cows was increased about $12 \%$ to guarantee the adequacy of the formulated ration. Feed exceeding the calculated ration was found almost entirely as refusal, confirming that the calculated ration met the nutritional requirements

Table 1. Ingredients of the experimental diets, chemical composition, and $\mathrm{NE}_{\mathrm{L}}$ of $\operatorname{diet}(\mathrm{DM}$ basis)

\begin{tabular}{|c|c|c|c|c|}
\hline \multirow[b]{2}{*}{ Item } & \multicolumn{4}{|c|}{$\operatorname{Diet}^{1}$} \\
\hline & $\mathrm{C}$ & $\mathrm{FS}^{2}$ & FS+GLN & $\mathrm{GLN}^{3}$ \\
\hline Concentrate, ${ }^{4} \%$ & 60.87 & 54.39 & 52.8 & 59.43 \\
\hline Corn, \% & 5.37 & 5.39 & 5.23 & 5.25 \\
\hline Oat hays, $\%$ & 33.76 & 33.86 & 32.88 & 32.96 \\
\hline Whole flaxseed, \% & 0 & 6.90 & 6.70 & 0 \\
\hline Glutamine, \% & 0 & 0 & 2.39 & 2.36 \\
\hline $\mathrm{DM}, \%$ & 92.06 & 92.79 & 92.41 & 92.22 \\
\hline Ether extract, $\%$ of DM & 3.20 & 5.44 & 6.98 & 4.53 \\
\hline $\mathrm{CP}, \%$ of $\mathrm{DM}$ & 15.33 & 15.20 & 15.69 & 15.9 \\
\hline $\mathrm{ADF}, \%$ of $\mathrm{DM}$ & 23.03 & 23.15 & 22.47 & 22.48 \\
\hline $\mathrm{NDF}, \%$ of $\mathrm{DM}$ & 41.18 & 41.17 & 39.98 & 40.21 \\
\hline $\mathrm{ADL}, \%$ of $\mathrm{DM}$ & 4.01 & 4.15 & 4.03 & 3.92 \\
\hline $\mathrm{NE}_{\mathrm{L}},{ }^{5} \mathrm{Mcal} / \mathrm{kg}$ & 1.68 & 1.65 & 1.73 & 1.72 \\
\hline \multicolumn{5}{|c|}{$\begin{array}{l}{ }^{1} \text { Diet: } \mathrm{C}=\text { control diet; FS }=\text { supplementation based on whole flaxseed; FS+GLN = supplementation based } \\
\text { on whole flaxseed and glutamine; GLN = supplementation based on glutamine. } \\
{ }^{2} \text { Lin Tech (Tecnozoo srl, Torreselle di Piombino Dese, Italy). } \\
{ }^{3} \mathrm{~L} \text {-Glutamine } 40 \% \text { (Ascor Chimici srl, Capocolle di Bertinoro, Italy). } \\
{ }^{4} \text { Contained: corn meal, roasted soybean meal, wheat germ meal, wheat meal, roasted soybean seeds, barley } \\
\text { meal, wheat fine bran, sugarcane molasses, partially debarked sunflower meal, calcium carbonate, calcium } \\
\text { hydrogen phospate, sodium bicarbonate, sodium chloride, magnesium oxide, } 40 \mathrm{IU} / \mathrm{g} \text { vitamin A, } 4 \mathrm{IU} / \mathrm{g} \text { vita- } \\
\text { min } \mathrm{D}_{3}, 0.004 \% \text { vitamin E, } 0.0005 \% \text { vitamin } \mathrm{B}_{1}, 0.0002 \% \text { vitamin } \mathrm{B}_{2}, 0.02 \text { vitamin PP, } 0.05 \% \mathrm{Cl}, 0.003 \% \mathrm{Fe} \text {, } \\
0.00025 \% \mathrm{Co}, 0.0006 \% \mathrm{I}, 0.009 \% \mathrm{Mn}, 0.001 \% \mathrm{Cu}, 0.025 \% \mathrm{Zn}, 0.00003 \% \mathrm{Se} \text {. } \\
{ }^{5} \text { Calculated according to NRC }(2001 \text {. }\end{array}$} \\
\hline
\end{tabular}


of cows. Water was available ad libitum. A sample from each experimental diet was taken weekly, frozen, and used for chemical analyses. The chemical composition of diets was determined by standard procedures (AOAC, 1990; Table 1). Briefly, ether extract was determined by the Soxhlet method using petroleum ether and CP was determined using the Kjeldahl method. Acid detergent fiber was determined according to Van Soest (1963a), and NDF and ADL according to Van Soest (1963b) using chemical extraction followed by gravimetric determination of the residues.

Fatty acid analysis of feed ingredients of the diet was carried out according to Sukhija and Palmquist (1988). Fatty acid methyl esters (FAME) were analyzed on an Agilent 6890N gas chromatograph (Santa Clara, CA). Separation of the FAME was performed using a DB 23 fused-silica capillary column $[60 \mathrm{~m} \times 0.25 \mathrm{~mm}$ (i.d.) with $0.25 \mu \mathrm{m}$ film thickness]. Operating conditions were a helium flow rate of $1.2 \mathrm{~mL} / \mathrm{min}$, FID detector at $250^{\circ} \mathrm{C}$, a split-splitless injector at $240^{\circ} \mathrm{C}$, and an injection volume of $1 \mu \mathrm{L}$ with a split ratio $1: 50$. The initial column temperature was set at $60^{\circ} \mathrm{C}$, increased to $180^{\circ} \mathrm{C}$ at $25^{\circ} \mathrm{C} / \mathrm{min}$ and finally increased to $230^{\circ} \mathrm{C}$ at $6^{\circ} \mathrm{C} / \mathrm{min}$ and held for $15 \mathrm{~min}$. Retention time and area of each peak were computed using the 6890N Network GC system software (Agilent). Individual FAME peaks were identified by comparing their retention times with those of defined standards (Sigma-Aldrich, Milan, Italy): FAME mix 37 components Matreya (SigmaAldrich). Results were expressed as percent of total FA analyzed (Table 2).

\section{Milk Sampling and Analysis}

Milk yield was carried out at 0600 and $1700 \mathrm{~h}$ and monitored daily by means of graduated measuring cylinders attached to individual milking units. Individual milk samples were collected at morning and afternoon milkings every $14 \mathrm{~d}$ for the duration of the experiment. Milk samples were carried in our laboratory by means of transport tankers at $4^{\circ} \mathrm{C}$. One aliquot was stored at $-20^{\circ} \mathrm{C}$ for FA analysis. Fresh samples were used for chemical analysis consisting of measurements for $\mathrm{pH}$ (GLP 21 Crison, Spain), total protein, CN, fat, and lactose content using an infrared spectrophotometer (MilkoScan FT120, Foss Electric, Hillerød, Denmark) according to the International Dairy Federation standard (IDF, 1990), and SCC using a Fossomatic Minor (Foss Electric; IDF, 1995).

For the analysis of milk FA, milk fat was extracted according to the procedure of Luna et al. (2005) and transesterification of FA was carried out according to ISO-IDF (2002) procedures. Fatty acid methyl esters were separated and measured using a gas chromatograph (Agilent $6890 \mathrm{~N}$ ) equipped with CP-Sil 88 fusedsilica capillary column $[100 \mathrm{~m} \times 0.25 \mathrm{~mm}$ (i.d.) with $0.25 \mu \mathrm{m}$ film thickness]. Operating conditions were a helium flow rate of $1 \mathrm{~mL} / \mathrm{min}$, an FID detector at $260^{\circ} \mathrm{C}$, a split-splitless injector at $260^{\circ} \mathrm{C}$, and an injection volume of $1 \mu \mathrm{L}$ with a split ratio 1:50. The temperature program of the column was set at $100^{\circ} \mathrm{C}$ and subsequently increased to $240^{\circ} \mathrm{C}$ at $3.5^{\circ} \mathrm{C} / \mathrm{min}$ and held for $15 \mathrm{~min}$. Each peak was identified using standard from Matreya (Sigma-Aldrich). Fatty acids were reported as gram per $100 \mathrm{~g}$ of total FAME and SFA, MUFA, and PUFA were calculated.

\section{Establishment of Humoral Response to a Nominal Antigen Chicken Egg Albumin}

At the start of the experiment, d 0, $2 \mathrm{mg}$ of chicken egg albumin (OVA; Sigma Chemical Co., Milan, Italy), dissolved in $1 \mathrm{~mL}$ of sterile saline solution and $1 \mathrm{~mL}$ of incomplete Freund's adjuvant (Sigma Chemical Co.), was injected subcutaneously into both shoulders of each cow. A subsequent injection of $2 \mathrm{mg}$ of OVA in saline without adjuvant was administered $15 \mathrm{~d}$ later.

\section{Sampling of Cow Blood for the Preparation of Plasma}

Blood was taken from the caudal vein from each cow at d 0, 15, 30, 45, and 60 of the experiment. Samples were collected into duplicate heparinized vacuum tubes (Becton Dickinson, Plymouth, UK) for each animal;

Table 2. Fatty acid composition of feed ingredients (DM basis)

\begin{tabular}{lrrrrl}
\hline & \multicolumn{5}{c}{ Ingredient } \\
\cline { 2 - 5 } FA, \% of & Concentrate & Corn & Oat hay & Flaxseed & Glutamine \\
total FA & 2.69 & 0.35 & 9.38 & 0.06 & - \\
\hline C14:0 & 17.74 & 24.06 & 27.10 & 5.53 & - \\
C16:0 & 0.37 & 0.11 & 1.65 & 0.08 & - \\
C16:1 & 4.45 & 2.97 & 11.57 & 3.56 & - \\
C18:0 & 29.72 & 26.70 & 26.41 & 16.29 & - \\
C18:1n-9 cis & 36.13 & 39.96 & 3.19 & 16.75 & - \\
C18:2n-6 cis-9, cis-12 & 5.15 & 2.17 & 1.88 & 53.21 & - \\
C18:3n-3 & & & & & \\
\hline
\end{tabular}


they were immediately put on ice and transported to our laboratory to be analyzed. Blood samples were centrifuged at $1200 \times g$ for $15 \mathrm{~min}$ at $25^{\circ} \mathrm{C}$ to obtain plasma. Plasma samples were collected and aliquoted in 6 replicates for each animal, and then stored at $-80^{\circ} \mathrm{C}$, until analysis of anti-OVA IgG titers, IL-1 $\beta$, IL-6, and IL-10 concentrations.

\section{Anti-OVA Specific IgG ELISA}

Plasma antibody titer was evaluated by an ELISA test performed in 96-well, U-bottomed microtiter plates according to Caroprese et al. (2006). Briefly, wells were coated with $100 \mu \mathrm{L}$ of antigen at $4^{\circ} \mathrm{C}$ for $12 \mathrm{~h}$, washed and incubated with $1 \%$ skim milk at $37^{\circ} \mathrm{C}$ for $1 \mathrm{~h}$ to reduce nonspecific binding. After washing, plasma from each cow was added and incubated at $37^{\circ} \mathrm{C}$ for $1 \mathrm{~h}$. The extent of antibody binding was detected using a horseradish peroxidase-conjugated (HRP) donkey anti-bovine IgG (Sigma Chemical Co.). Optical density was measured at a wavelength of $450 \mathrm{~nm}$. Plasma samples were read against a standard curve obtained using scalar dilution of bovine IgG (Sigma Chemical Co.). Data were expressed as nanograms of anti-OVA IgG per $100 \mu \mathrm{L}$.

\section{Determination of IL-1 $\beta$, IL-6, and IL-10 Production by ELISA}

The detection of IL-6, IL-1 $\beta$, and IL10 in plasma was determined by capture ELISA performed on 96-well microtiter plates according to Caroprese et al. (2009) with some modifications. Mouse monoclonal antibodies for bovine IL-6 and for ovine IL-1 $\beta$ (Serotec Ltd., Kidlington, UK) dissolved in $50 \mathrm{~m} M$ carbonate buffer ( $\mathrm{pH}$ 9.6) were used to coat wells and incubated overnight at $4^{\circ} \mathrm{C}$. After washing with PBS $(\mathrm{pH} 7.2)$ and $0.05 \%$ Tween 20 (PBST) plates were incubated with $100 \mu \mathrm{L}$ of $3 \%$ BSA diluted in PBST at room temperature for 1 $\mathrm{h}$ to block nonspecific binding. Plates were then washed 2 times with PBST and the plasma $(50 \mu \mathrm{L} /$ well $)$ was added and incubated at room temperature for $1.5 \mathrm{~h}$. Buffer alone or 3\% BSA in PBST provided negative control wells. Rabbit polyclonal antibody anti-ovine IL-6 and anti-bovine IL-1 $\beta$ conjugated to biotin (Serotec Ltd.) were used as detecting antibodies (1:500 diluted in $3 \% \mathrm{BSA}$ in PBST) to determine captured IL-6 and IL-1 $\beta$ and incubated at room temperature for $1.5 \mathrm{~h}$. The presence of IL-6 was detected using goat anti-rabbit IgG conjugated to HRP (Sigma Aldrich). After a further washing, $100 \mu \mathrm{L}$ of substrate consisting of tetra methyl benzidine-free base tablets (Sigma Aldrich), dimethyl sulfoxide (Sigma Aldrich) dissolved in $0.05 M$ phosphate-citrate buffer ( $\mathrm{pH} 5.0)$, and $\mathrm{H}_{2} \mathrm{O}_{2}$ was added to each well and incubated for $30 \mathrm{~min}$ at $37^{\circ} \mathrm{C}$. Finally, $2 \mathrm{M}$ of $\mathrm{H}_{2} \mathrm{SO}_{4}$ was added to terminate reactions. Concentrations of IL- $1 \beta$ were detected using streptavidin conjugated to HRP. The substrate used was the same as for detection of IL-6. Plasma samples for IL-1 $\beta$ determination were read against a standard curve obtained using scalar dilution of bovine IL-1 $\beta$ (Serotec Ltd.), and data were expressed as nanograms of IL-1 $\beta$ per milliliter. Data for IL-6 and IL-10 were expressed as relative optical densities.

\section{Evaluation of the Cell-Mediated Immune Response}

At d 0, 30, and 60, lymphocyte proliferation was determined in vivo on each cow by the measurement of changes in skin-fold thickness in response to intradermal injection with $1 \mathrm{mg} / \mathrm{mL}$ of phytohemagglutinin (Sigma Chemical Co.) dissolved in $1 \mathrm{~mL}$ of sterile saline solution. At each sampling time, the injection was administered into the center of a circle, $2 \mathrm{~cm}$ in diameter, marked on shaved skin on the upper side of each shoulder. The determination of lymphocyte proliferation, measured as skinfold thickness, was calculated from the 2 measurements made with calipers as the difference between 24-h postinjection thickness and preinjection thickness.

\section{Statistical Analysis}

All variables were tested for normality using the Shapiro-Wilk test (Shapiro and Wilk, 1965) and transformed in logarithmic form to normalize their frequency distribution, when necessary. Then data were processed by ANOVA, using the GLM procedure for repeated measures of SAS Institute (1999). For milk and immunological data the model was

$$
\mathrm{y}_{\mathrm{ijkl}}=\mu+\alpha_{\mathrm{i}}+\beta_{\mathrm{ij}}+\gamma_{\mathrm{k}}+(\alpha \gamma)_{\mathrm{ik}}+\varepsilon_{\mathrm{ijkl}},
$$

where $\mu=$ the overall mean; $\alpha=$ feeding treatment; $\beta$ $=$ animal effect within feeding treatment; $\gamma=$ day of sampling effect; $\alpha \gamma=$ interaction of feeding treatment $\times$ day of sampling; and $\varepsilon=$ error. When significant effects were found (at $P<0.05$ ), the Student $t$-test was used to locate significant differences between means.

\section{RESULTS}

\section{Meteorological Data}

Maximum THI was always higher than 72 during the experiment. During the hottest day, maximum THI ranged from 86 to 87.6, whereas minimum THI ranged from 75 to 79 . Mean daily THI averaged 72 and 
peaked to 81 during the hottest day of the experiment (Figure 1). During the experiment, 3 heat weaves were registered: the first heat wave had a duration of $3 \mathrm{~d}$, a mean THI of 79 , and a maximum THI of 83.6; the second wave had a duration of $4 \mathrm{~d}$, a mean THI of 77.6 , and a maximum THI of 83.7; the third heat wave had a duration of $5 \mathrm{~d}$, a mean THI of 78.4, and a maximum THI of 85.5.

\section{DMI, Milk Yield, and Chemical Analysis of Milk}

The DMI was $16.57 \mathrm{~kg} / \mathrm{d}$ for $\mathrm{C}$ cows, $16.60 \mathrm{~kg} / \mathrm{d}$ for FS cows, $16.96 \mathrm{~kg} / \mathrm{d}$ for GLN cows, and $17.00 \mathrm{~kg} / \mathrm{d}$ for FS+GLN cows $( \pm 0.2 \mathrm{SE})$. Cows in the experiment were not high-yielding cows. Cows fed FS and FS+ GLN had a higher milk yield than GLN cows, which in turn yielded more milk than $\mathrm{C}$ cows (Table 3). Such differences also emerged for protein, CN, and fat yields. Milk yield increased in FS and FS+GLN milk at d 15 of the experiment, fat yield increased starting from d 30 of the experiment (Figure 2). Casein and lactose contents were higher in $\mathrm{C}$ and $\mathrm{FS}$ cows than in GLN cows $(P<0.001$ and $<0.05$, respectively $)$. The lowest SCC was registered in GLN cows compared with the other groups $(P<0.001)$, and the highest in FS cows.

\section{FA Composition of Milk}

No significant differences were found in all groups for SFA, except for C16:0 (palmitic acid), which was significantly lower in FS and FS+GLN cows $(P<0.01)$, and for C18:0 (stearic acid), which was higher in FS and FS+GLN cows $(P<0.05$; Table 4$)$. A treatment effect $(P<0.05)$ was found for PUFA proportion in milk, with the lowest PUFA content in the milk from GLN group. Linoleic acid (C18:2n-6 cis-9,cis-12) and C18:2n-6 cis-9,trans-11 contents were significantly higher $(P<0.001)$ in FS and FS+GLN cows than in GLN and C cows. As a result, the total CLA content was significantly higher in milk from FS and FS+GLN groups than in GLN and $\mathrm{C}$ groups $(P<0.001)$. The C20:5n-3 (eicosapentaenoic acid) content of milk $(P<$ 0.001 ) was higher in FS and FS+GLN cows.

\section{Immunological Determinations}

Cows fed the FS and GLN diets showed higher average anti-OVA IgG titers than FS+GLN cows $(P<$ 0.01 ). Humoral response assay showed the lowest antiOVA IgG titers in FS+GLN cows at d 45; at d 60 both $\mathrm{C}$ and FS+GLN cows showed lower IgG titers than FS and GLN cows (Figure 3). A time effect $(P<0.001)$

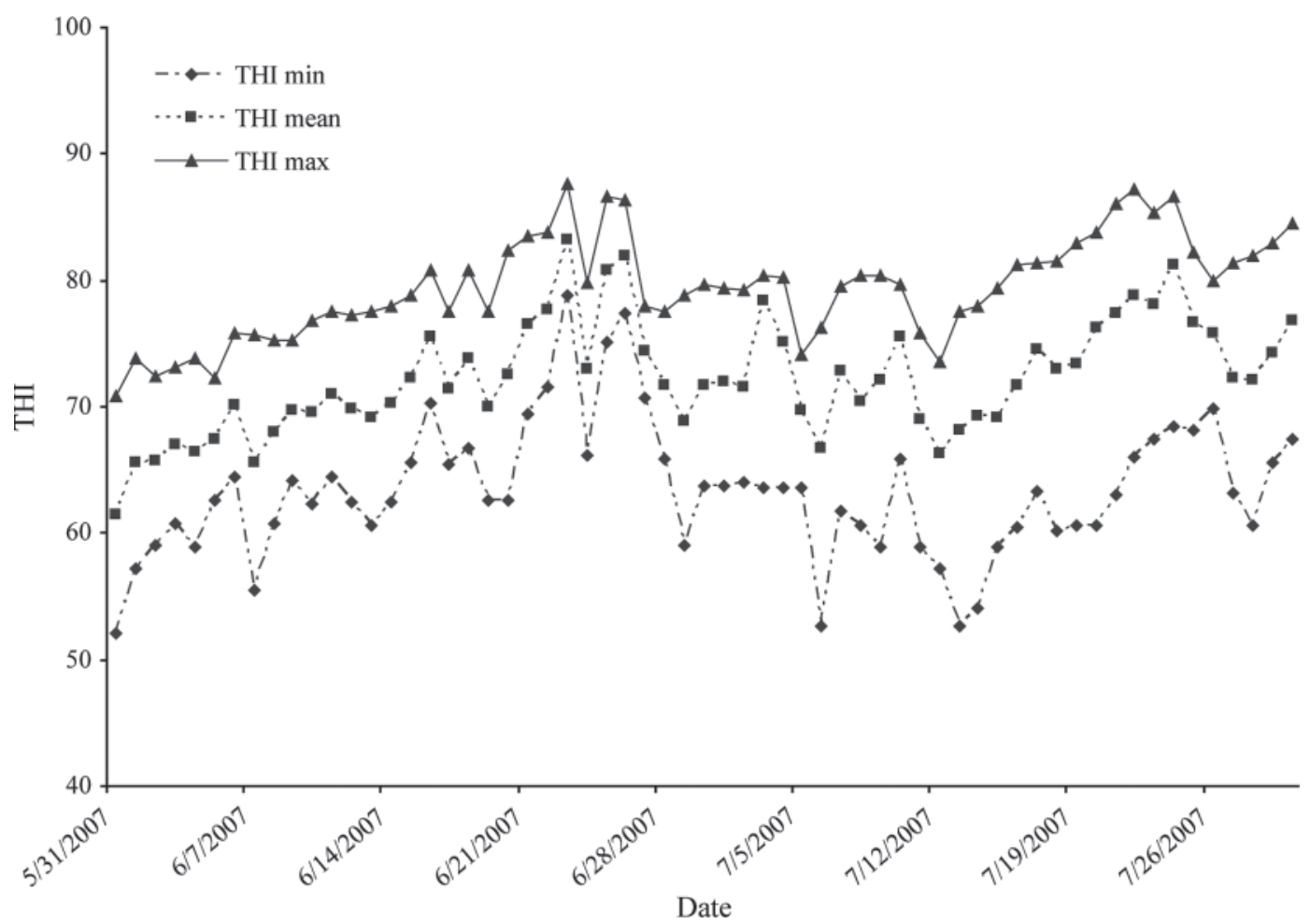

Figure 1. Daily averages of temperature-humidity index (THI) values (minimum, maximum, and mean) detected during the experimental period. 
Table 3. Least squares means \pm SEM of yield, composition, and hygienic quality of milk from cows fed the control diet (C), flaxseed (FS), flaxseed + glutamine (FS+GLN), or glutamine (GLN)

\begin{tabular}{|c|c|c|c|c|c|c|}
\hline Item & \multicolumn{4}{|c|}{ Treatment } & SEM & $\begin{array}{c}\text { Effects, } P \text {-value, } \\
\text { treatment }\end{array}$ \\
\hline Fat & $0.668^{\mathrm{c}}$ & $0.864^{\mathrm{a}}$ & $0.816^{\mathrm{a}}$ & $0.750^{\mathrm{b}}$ & 0.022 & $* * *$ \\
\hline Protein & $0.603^{\mathrm{c}}$ & $0.747^{\mathrm{a}}$ & $0.739^{\mathrm{a}}$ & $0.650^{\mathrm{b}}$ & 0.021 & $* * *$ \\
\hline Casein & $0.472^{\mathrm{c}}$ & $0.583^{\mathrm{a}}$ & $0.573^{\mathrm{a}}$ & $0.499^{\mathrm{b}}$ & 0.002 & $* * *$ \\
\hline Protein & 3.22 & 3.15 & 3.10 & 3.01 & 0.06 & NS \\
\hline Casein & $2.52^{\mathrm{a}}$ & $2.45^{\mathrm{a}}$ & $2.40^{\mathrm{ab}}$ & $2.31^{\mathrm{b}}$ & 0.01 & * \\
\hline Lactose & $4.81^{\mathrm{a}}$ & $4.81^{\mathrm{a}}$ & $4.78^{\mathrm{ab}}$ & $4.76^{\mathrm{b}}$ & 0.01 & $*$ \\
\hline \multicolumn{7}{|l|}{ Milk hygienic quality } \\
\hline $\mathrm{pH}$ & 6.63 & 6.64 & 6.61 & 6.63 & 0.01 & NS \\
\hline $\mathrm{SCC}, \log _{10}$ cells $/ \mathrm{mL}$ & $5.24^{\mathrm{b}}$ & $5.56^{\mathrm{a}}$ & $5.32^{\mathrm{b}}$ & $4.90^{\mathrm{c}}$ & 0.09 & $* * *$ \\
\hline
\end{tabular}

${ }^{\mathrm{a}-\mathrm{c}}$ Means within a row with different superscripts differ $(P<0.05)$.

${ }^{*} P<0.05 ;{ }^{* * *} P<0.001$.
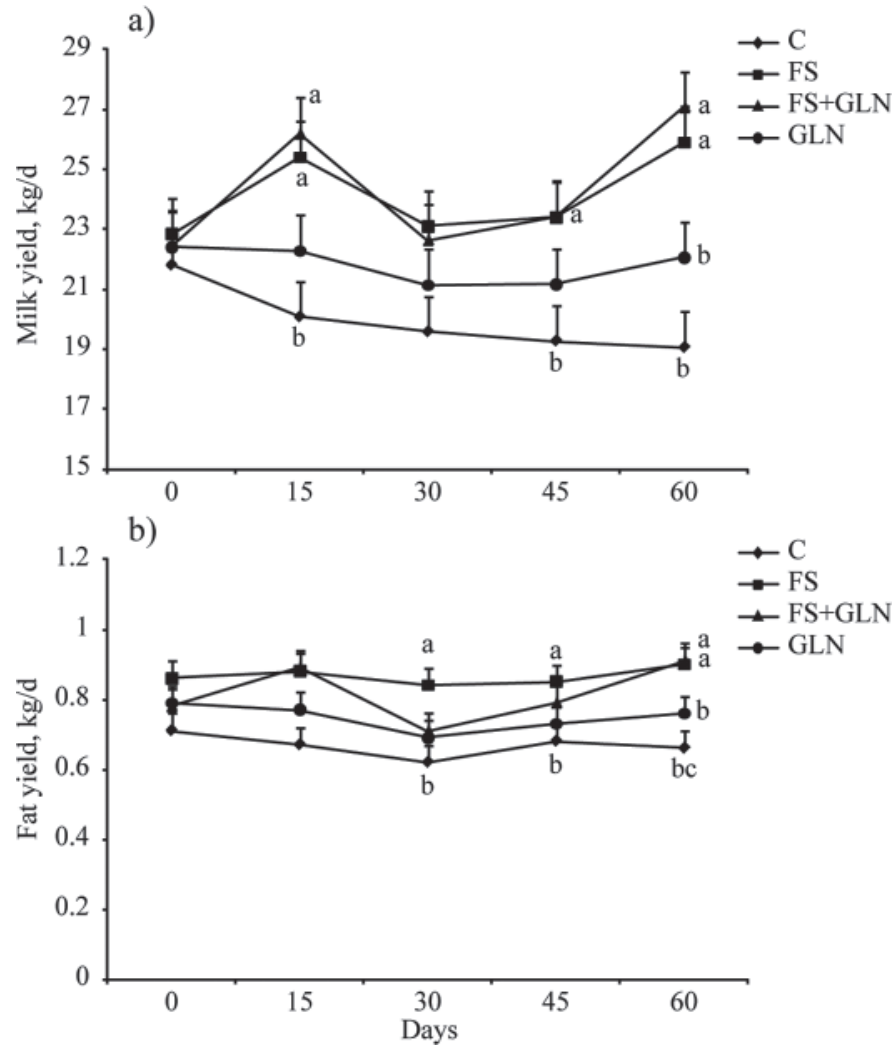

Figure 2. (a) Milk yield (LSM \pm SEM) of cows fed control diet (C), flaxseed (FS), flaxseed + glutamine (FS+GLN), or glutamine (GLN) measured at d 0, 15, 30, 45, and 60 of the trial (treatment effect $=P<0.001$; SEM $=0.80)$. (b) Fat yield $(\mathrm{LSM} \pm \mathrm{SEM})$ of cows fed C, FS, FS+GLN, or GLN measured at d $0,15,30,45$, and 60 of the trial (treatment effect $=P<0.001 ;$ SEM $=0.02$ ). Values with different superscripts $(\mathrm{a}-\mathrm{c})$ differ between treatments within a sampling day $(P<0.05)$ at the beginning of the trial (wk 0$)$ and then at wk 2, 4, 6 , 8,10 , and 12 of the trial. was found for $\operatorname{Ig} \mathrm{G}$ titer, because at d 15 of the trial a significant increase of humoral response was observed for all groups.

The IL-1 $\beta$ assay showed no significant differences among groups throughout the trial, even if at $\mathrm{d} 60$ IL-1 $\beta$ titers in FS cows were higher than IL-1 $\beta$ titers displayed by FS+GLN cows and cows fed no supplementation $(P<0.001$; Figure 4$)$. A time effect was also found $(P<0.001)$ because after $\mathrm{d} 30$ from the beginning of the trial, IL-1 $\beta$ secretion significantly increased until d 45, and then significantly decreased at d 60 in all the experimental groups apart from FS group.

Secretion of IL-6 was affected by treatment $(P<$ 0.01), IL-6 mean titers of FS+GLN and C groups being significantly higher than those of FS and GLN groups. An interaction of time $\times$ treatment was found $(P<$ 0.001) depending on GLN cows displaying a lower IL-6 secretion compared with FS+GLN and C groups at d 15 (Figure 5). A time effect was also found $(P<$ 0.001 ) because IL-6 secretion was higher at d 30 than in previous and subsequent samplings. Results obtained from IL-10 assay showed lower average production of IL-10 for GLN cows than for all other groups $(P<$ 0.01 , Figure 6). Increased average skinfold thickness was observed in GLN cows $(P<0.001)$; GLN cows had a higher cell-mediated immune response than $\mathrm{C}$ cows at $\mathrm{d} 30$ and higher than all the other 3 group at d 60 (Figure 7).

\section{DISCUSSION}

Maximum THI values collected were always higher than 72 , and mean THI values reached 77 ; in addition, 3 heat waves were registered during the experiment, demonstrating the existence of stressful conditions for cows. Indeed, when evaluating the relation between THI 


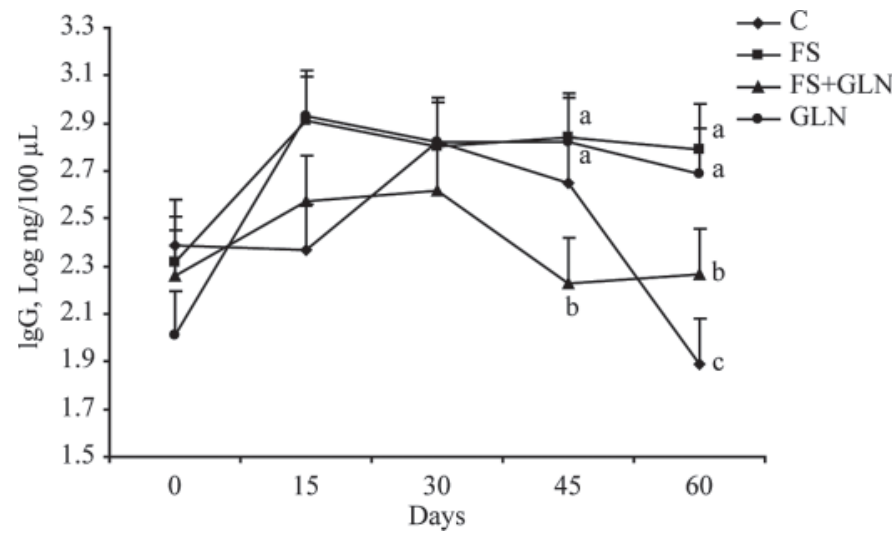

Figure 3. Antibody titers to chicken egg albumin (LSM \pm SEM) detected in blood of cows fed control diet (C), flaxseed (FS), flaxseed + glutamine (FS+GLN), or glutamine (GLN) at d 0, 15, 30, 45, and 60 of the trial (treatment effect $=P<0.01$; SEM $=0.15$ ). Values with different superscripts $(\mathrm{a}-\mathrm{c})$ differ between treatments within a sampling day $(P<0.05)$

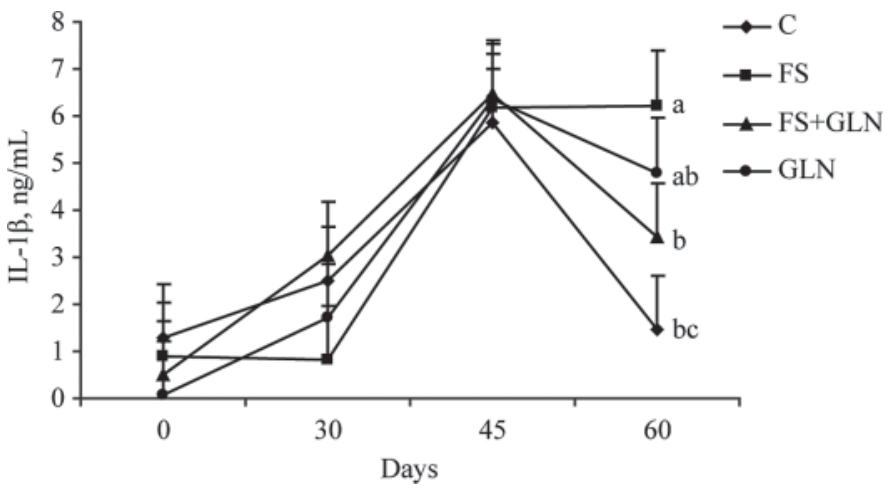

Figure 4. Interleukin-1 $\beta$ secretion (LSM \pm SEM) detected in blood of cows fed control diet (C), flaxseed (FS), flaxseed + glutamine (FS+GLN), or glutamine (GLN) at d 0,15, 30, 45, and 60 of the trial (treatment effect was not significant; SEM $=1.15$ ). Values with different superscripts $(\mathrm{a}-\mathrm{c})$ differ between treatments within a sampling day $(P<0.05)$.

Table 4. Least squares means \pm SEM of FA composition of milk (g/100 g of total FA) from cows fed the control diet (C), flaxseed (FS), flaxseed + glutamine $(\mathrm{FS}+\mathrm{GLN})$, or glutamine $(\mathrm{GLN})$

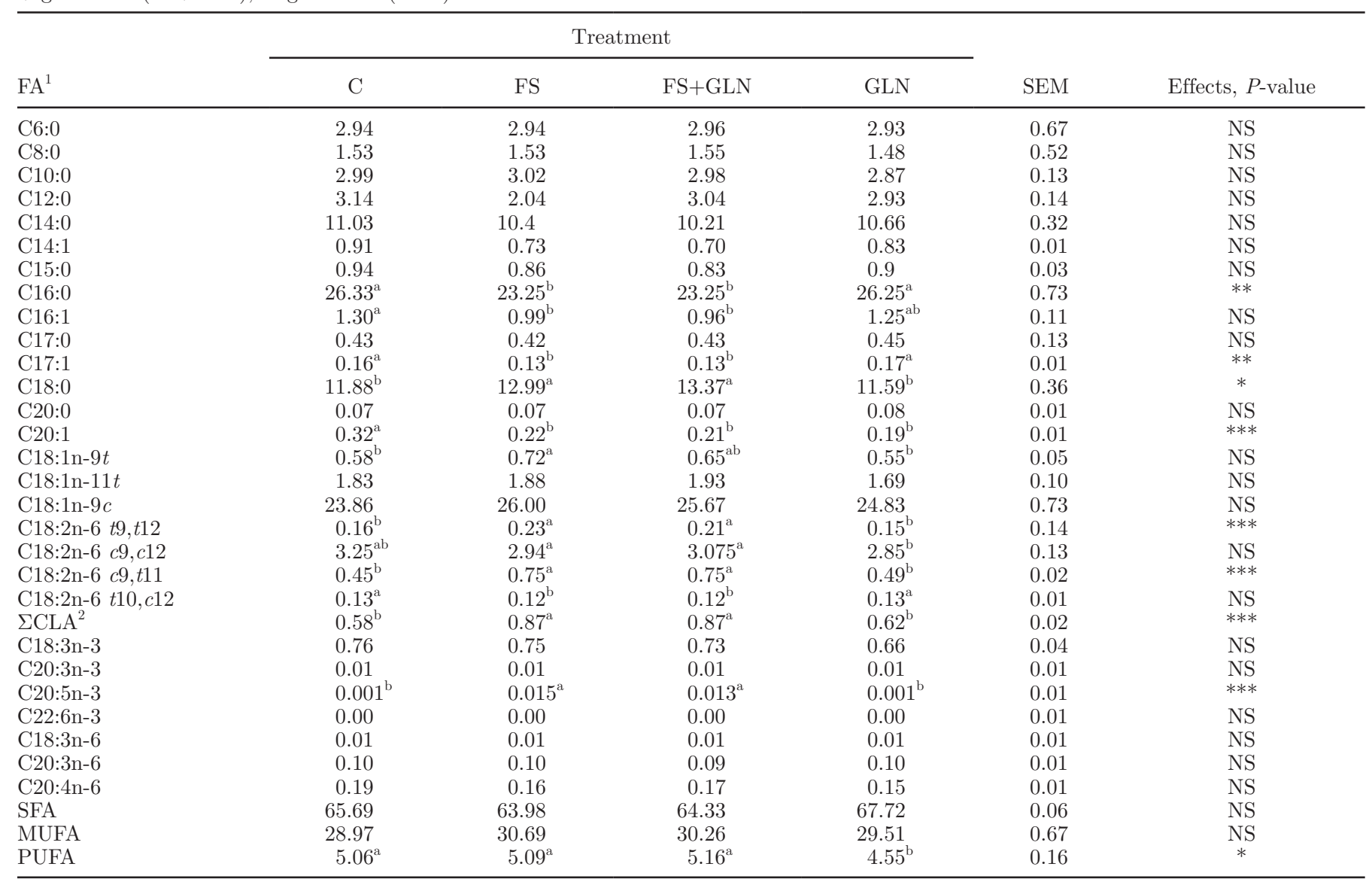

${ }^{\mathrm{a}, \mathrm{b}}$ Means within a row with different superscripts differ $(P<0.05)$.

${ }^{1} c=$ cis; $t=$ trans.

${ }^{2} \Sigma \mathrm{CLA}=\mathrm{C} 18: 2 \mathrm{n}-6 c 9, t 11+\mathrm{C} 18: 2 \mathrm{n}-6$ t10,c12. CLA $=$ conjugated linoleic acid.

${ }^{*} P<0.05 ;{ }^{* * *} P<0.001$. 


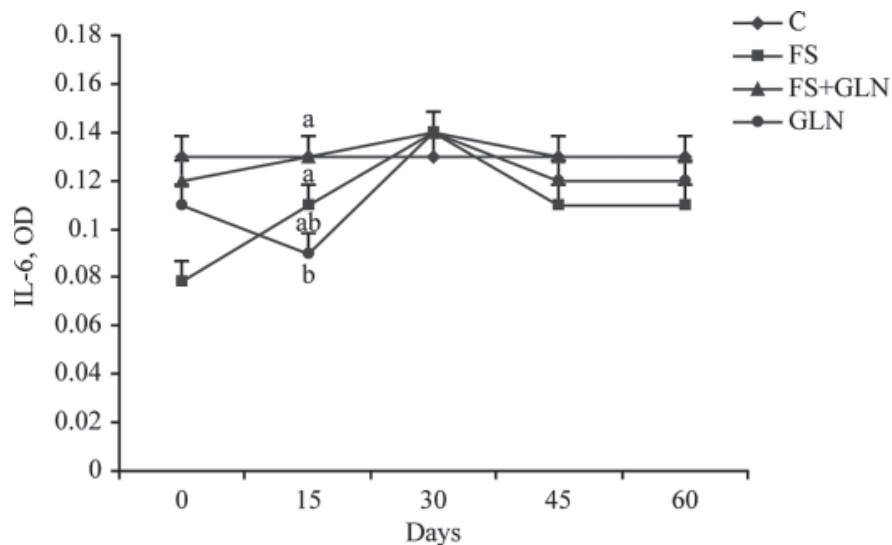

Figure 5. Interleukin-6 secretion (LSM $\pm \mathrm{SEM})$ detected in blood of cows fed control diet (C), flaxseed (FS), flaxseed + glutamine (FS+GLN), or glutamine (GLN) at d $0,15,30,45$, and 60 of the trial (treatment effect $=P<0.01 ; \mathrm{SEM}=0.01)$. Values with different superscripts $(\mathrm{a}, \mathrm{b})$ differ between treatments within a sampling day $(P<$ $0.05) . \mathrm{OD}=$ optical density.

and thermoregulatory ability of lactating cows, Kadzere et al. (2002) suggests considering THI values of 75 to 78 as stressful for cows, and THI values greater than 78 as extremely stressful, as cows are no longer able to maintain thermoregulatory mechanisms or normal body temperature. Cows supplemented with flaxseed combined with Gln showed an increase in milk, fat, protein, CN yields, confirming results already reported in our first trial on flaxseed supplementation to dairy cows under heat stress (Caroprese et al., 2010). Interestingly, GLN cows yielded more milk, with higher fat, protein, and CN yields than $\mathrm{C}$ cows, even though the improvements obtained were lower than those observed

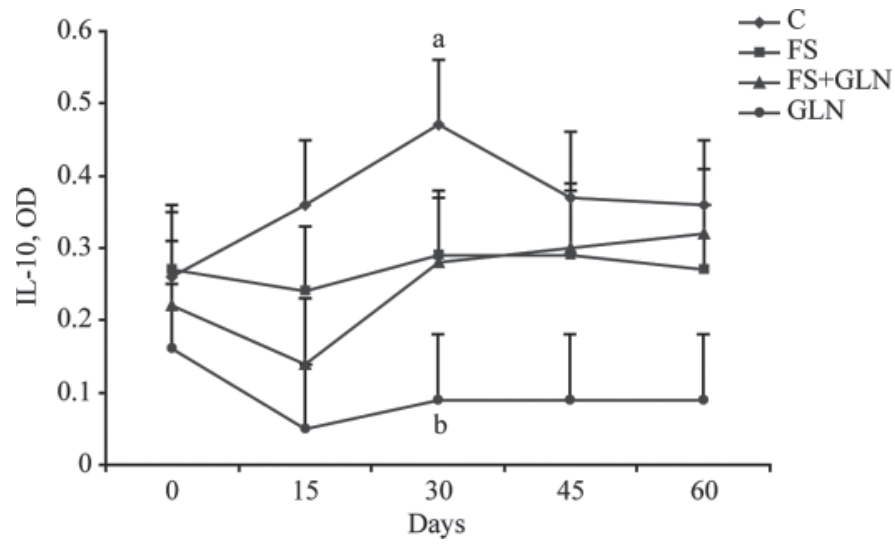

Figure 6. Interleukin-10 secretion (LSM \pm SEM) detected in blood of cows fed control diet (C), flaxseed (FS), flaxseed + glutamine (FS+GLN), or glutamine (GLN) at d $0,15,30,45$, and 60 of the trial (treatment effect $=P<0.01 ; \mathrm{SEM}=0.09$ ). Values with different superscripts $(\mathrm{a}, \mathrm{b})$ differ between treatments within a sampling day $(P<$ $0.05)$. OD = optical density.

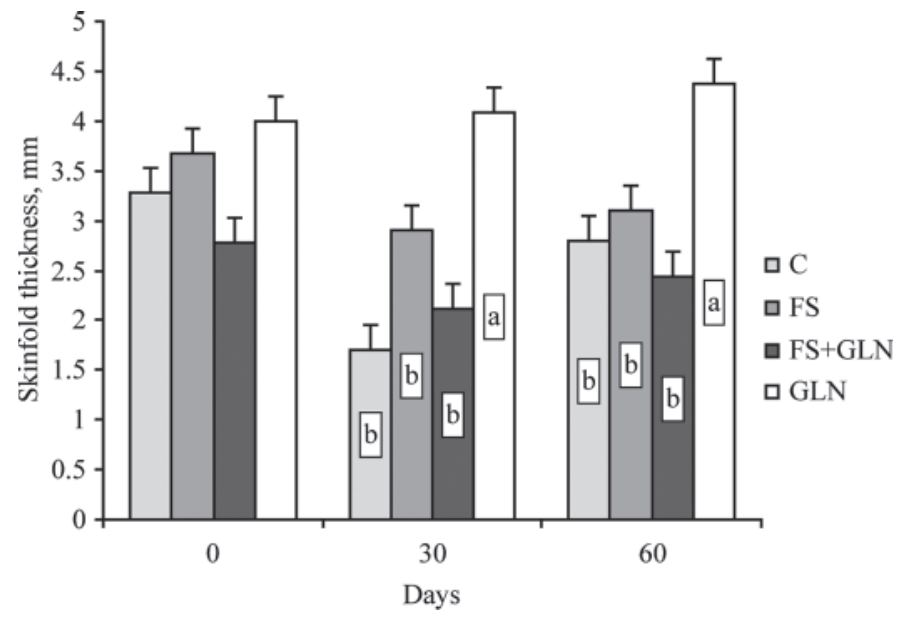

Figure 7. Skin fold thickness (LSM \pm SEM) after phytohemagglutinin injection detected in cows fed control diet (C), flaxseed (FS), flaxseed + glutamine (FS+GLN), or glutamine (GLN) measured at the beginning of the trial, and then at $\mathrm{d} 30$ and 60 of the trial (treatment effect: $P<0.001 ;$ SEM $=0.25)$. Values with different superscripts $(\mathrm{a}, \mathrm{b})$ differ $(P<0.05)$.

in milk from FS+GLN and FS cows. The increase in milk production was not the effect of increased DMI, because DMI was similar among groups. Results from present experiment are of particular interest, considering that in a previous study the administration of Gln by infusion to high-producing cows did not lead to a consistent improvement of milk yield and protein in mid lactation (Metcalf et al., 1996). Moreover, Gln infusion during early lactation, when the onset of lactation requires a great metabolic challenge as protein demand, did not result in an increase of milk protein synthesis despite a milk yield increase of $3 \%$ (Doepel at al., 2007). In this study, the dietary administration of Gln under high ambient temperature increased milk yield by $13 \%$ in the GLN cows and by $27 \%$ in the FS+GLN cows, demonstrating that cows under a hot climate could benefit from Gln administration. Present data showing the efficacy of Gln in sustaining cow milk production under high ambient temperature confirm the essential role of Gln in response to adverse challenges (Lobley et al., 2001).

The supplementation based on the combination of flaxseed and Gln improved the nutritional profile of milk with an increase in the contents of CLA, eicosapentaenoic acid, and PUFA, which are recognized as beneficial for human health and potentially able to reduce the risks of cardiovascular diseases. The improvement in FA composition of cow milk from a human health perspective, both in FS+GLN and in FS cows, was also apparent in terms of the reduction of the palmitic acid content, which has an hypercholesterolemic effect in human (Berner, 1993). The addition of Gln to the diet 
of cows fed flaxseed did not negatively influence the FA profile of milk, which was very similar to the FA profile of milk from cows fed flaxseed alone. On the contrary, the FA profile of milk from GLN cows was very similar to milk from the $\mathrm{C}$ group. Although no reports are available on the effect of the dietary administration of flaxseed in combination with AA, it can be assumed that Gln does not interfere with the FA composition in milk. Bauman and Griinari (2003) hypothesized that dietary PUFA can control the expression of enzymes implicated in the uptake, transport, and synthesis of de novo FA. when feeding diets with a high protein concentration $(18 \%)$ in combination with flaxseed to dairy cows, Petit et al. (2005) found that the increase in protein concentration of the diet resulted in changes of milk FA similar to those obtained with flaxseed. These authors suggested a possible role of proteins in the regulation of the gene expression connected with lipid synthesis in the mammary gland.

Under metabolic stressors, however, plasma Gln concentrations can be lowered, suggesting that the reduction of Gln supply to immunocompetent cells can be the cause of the increased susceptibility to infections with pending stress conditions (Yaqoob and Calder, 1998). It is well known that under heat stress, dairy cows experience an impairment of immunological responses due to a reduction of lymphocyte proliferation and the alteration of cytokine productions. However, data on the effects of heat stress on cow immune responses are conflicting (Lacetera et al., 2002, 2005; Caroprese et al., 2009). Our data showed a strengthening of delayedtype hypersensitivity and humoral responses and a drop of IL-10 secretion in cows fed Gln, in contrast with results from our previous experiment (Caroprese et al., 2012). However, Chang et al. (1999) demonstrated that Gln affects IL-10 production in human peripheral blood mononuclear cells by eliciting agents and cellular sources and that Gln can influence the response connected to the balance between T helper cells of type 1 (Th1) and of type 2 (Th2). In Holstein cows, summer conditions characterized by the occurrence of extreme events, such as heat waves, can be responsible for a profound shift from cellular to humoral responses, which may lead to a reduction of lymphocyte proliferations and to modifications of resistance to diseases (do Amaral et al., 2011; Lacetera et al., 2005). Stress hormones can induce a Th1/Th2 imbalance by increasing the Th2 cytokine production, by reducing IL-12 secretion, which is a major inducer of Th1 differentiation, and by increasing IL-10 production, which is responsible for promoting humoral immunity (Elenkov and Chrousos, 1999). Reasonably, it could be hypothesized that cows from GLN group, benefiting of the Gln supplementation, maintained elevated levels of Th1/Th2 ratio, as suggested by the low production of IL-10. This may account for the increased cell-mediated responses registered in GLN cows. Some authors found that Gln can enhance the Th1 cytokine response in vitro, with a little effect on the Th2 cytokine response (Chang et al., 1999). Dietary Gln supplementation, however, can reverse the Th2type response in a more balanced Th1/Th2 response in septic mice (Yeh et al., 2005); thus, previous findings can be claimed to explain the high concentrations of antigen-driven IgG measured in plasma of GLN cows. Present results suggest that Gln supplementation can have different outcomes on cow immune responses depending on the type and intensity of stressors acting on animals. Our hypothesis is that the same nutrient can lead to a different activation of molecular pathways involved in immunological activation in response to different types of stressors. Glutamine administration in the diet of dairy cows can reduce inflammatory reactions when cows are not subjected to environmental stressors (Caroprese et al., 2012), or enhance immune responses when cows are subjected to homeostatic challenges, such as high ambient temperature. As a consequence, our data suggest that when cows are subjected to high ambient temperature, Gln can be considered as a nutrient required to maintain the proper function of immunological responses by maintaining appropriate levels of lymphocyte activations. The occurrence of enhanced immune responses in GLN cows can also explain the low milk-SCC levels found in GLN milk; a relation between cell-mediated immune responses and mastitis exists, with high cell-mediated immune responder cows having lower mastitis incidence than low cell-mediated immune responder cows (ThompsonCrispi et al., 2012). Glutamine administration could be recommended to improve hygienic quality of cow milk, according to previous findings (Caroprese et al., 2012).

Cows fed an FS diet displayed enhanced humoral immune responses and IL- $1 \beta$ secretions, in agreement with previous studies, suggesting that flaxseed administration in cows can successfully sustain ruminant immune responses under high ambient temperature (Caroprese et al., 2009). Some considerations may arise from the observation that FS+GLN cows showed immunological responses similar to cows receiving no supplementation. In particular, FS+GLN cows showed in vivo lymphocyte proliferation, humoral responses to antigens, and cytokine secretions closer to nonsupplemented cows than to FS or GLN cows. It could be hypothesized that the combined administration of flaxseed and Gln can exert a conflicting effect on immune responses resulting in a lower effect than when administered alone. Further studies are required to better understand the molecular mechanisms by which Gln and flaxseed act on immune cells under stress conditions. 


\section{CONCLUSIONS}

In conclusion, Gln administration has been shown to be beneficial to dairy cows under a hot climate by sustaining cow immune reactions in terms of a strengthening of cell-mediated immune response, which is weakened in cows under heat stress. Glutamine administration also contributed to improved milk, fat, protein, and CN yields. On the contrary, Gln administration in combination with flaxseed resulted in a reduction of immunological reactivity, nullifying the effects of both Gln and flaxseed on immune reactions when administered alone. When evaluating Gln administration in combination with flaxseed on milk production and milk fat profile, our results showed that Gln did not further improve the positive and demonstrated effects of flaxseed administration.

\section{ACKNOWLEDGMENTS}

The authors thank Concetta Perilli and Alessandra Marzano (both from the Department of the Sciences of Agriculture, Food and Environment (SAFE), University of Foggia, Foggia, Italy) for expert technical assistance.

\section{REFERENCES}

AOAC. 1990. Official Methods of Analysis. Vol. I. 15th ed. Association of Official Analytical Chemists, Arlington, VA.

Bauman, D. E., and J. M. Griinari. 2003. Nutritional regulation of milk fat synthesis. Annu. Rev. Nutr. 23:203-227.

Berner, L. A. 1993. Round table discussion on milk fat, dairy foods and coronary heart disease risk. J. Nutr. 123:1175-1184.

Caroprese, M., M. Albenzio, G. Annicchiarico, and A. Sevi. 2006. Changes occurring in immune responsiveness of single- and twinbearing comisana ewes during the transition period. J. Dairy Sci. 89:562-568.

Caroprese, M., M. Albenzio, R. Marino, A. Santillo, and A. Sevi. 2012. Immune response and milk production of dairy cows fed graded levels of rumen-protected glutamine. Res. Vet. Sci. 93:202-209.

Caroprese, M., A. Marzano, G. Entrican, S. Wattegedera, M. Albenzio, and A. Sevi. 2009. Immune response of cows fed polyunsaturated fatty acids under high ambient temperatures. J. Dairy Sci. 92:2796-2803.

Caroprese, M., A. Marzano, R. Marino, G. Gliatta, A. Muscio, and A. Sevi. 2010. Flaxseed supplementation improves fatty acid profile of cow milk. J. Dairy Sci. 93:2580-2588.

Chang, W. K., K. D. Yang, and M. F. Shaio. 1999. Effect of glutamine on Th1 and Th2 cytokine responses of human peripheral blood mononuclear cells. Clin. Immunol. 93:294-301.

do Amaral, B. C., E. E. Connor, S. Tao, M. J. Hayen, J. W. Bubolz, and G. E. Dahl. 2011. Heat stress abatement during the dry period influences metabolic gene expression and improves immune status in the transition period of dairy cows. J. Dairy Sci. 94:86-96.

Doepel, L., G. E. Lobley, J. F. Bernier, and H. Lapierre. 2007. Effect of glutamine supplementation on splanchnic metabolism in lactating dairy cows. J. Dairy Sci. 90:4325-4333.

Elenkov, I. J., and G. P. Chrousos. 1999. Stress hormones, Th1/Th2 patterns, pro/anti-inflammatory cytokines and susceptibility to disease. Trends Endocrinol. Metab. 10:359-368.

IDF. 1990. Determination of milk fat, protein and lactose contentGuide for the operation of mid-infra-red instruments. FIL-IDF Standard no. 141B, Brussels, Belgium.
IDF. 1995. Enumeration of somatic cells. FIL-IDF Standard no. 148A, Brussels, Belgium.

ISO-IDF. 2002. Milk fat-Preparation of fatty acid methyl esters. International Standard ISO 15884-IDF 182:2002. International Dairy Federation, Brussels, Belgium.

Kadzere, C. T., M. R. Murphy, N. Silanikove, and E. Maltz. 2002. Heat stress in lactating dairy cows: A review. Livest. Prod. Sci. 77:59-91.

Kelly, C. F., and T. E. Bond. 1971. Bioclimatic Factors and their Measurement. A Guide to Environmental Research on Animals. Natl. Acad. Sci., Washington, DC.

Lacetera, N., U. Bernabucci, B. Ronchi, D. Scalia, and A. Nardone. 2002. Moderate summer heat stress does not modify immunological parameters of Holstein dairy cows. Int. J. Biometeorol. 46:33-37.

Lacetera, N., U. Bernabucci, D. Scalia, B. Ronchi, G. Kuzminsky, and A. Nardone. 2005. Lymphocyte functions in dairy cows in hot environment. Int. J. Biometeorol. 50:105-110.

Liu, Z. L., P. Chen, J. M. Li, S. B. Lin, D. M. Wang, and D. P. Yang. 2008. Effect of dietary sources of roasted oilseeds on blood parameters and milk fatty acid composition. Czech J. Anim. Sci. $53: 219-226$.

Lobley, G. E., S. O. Hoskin, and C. J. McNeil. 2001. Glutamine in animal science and production. J. Nutr. 131:2525S-2531S.

Luna, P., J. M. Juárez, and M. A. de la Fuente. 2005. Validation of a rapid milk fat separation method to determine the fatty acid profile by gas chromatography. J. Dairy Sci. 88:3377-3381.

Meijer, G. A. L., J. Van der Meulen, J. G. M. Bakker, C. J. Van der Koelen, and A. M. Van Vuuren. 1995. Free amino acids in plasma and muscle of high yielding dairy cows in early lactation. J. Dairy Sci. 78:1131-1141.

Metcalf, J. A., L. A. Crompton, D. Wray-Cahen, M. A. Lomax, J. D. Sutton, D. E. Beever, J. C. MacRae, B. J. Bequette, F. R. C. Backwell, and G. E. Lobley. 1996. Responses in milk constituents to intravascular administration of two mixtures of amino acids to dairy cows. J. Dairy Sci. 79:1425-1429.

Moore, C. E., J. K. Kay, M. J. VanBaale, R. J. Collier, and L. H. Baumgard. 2005. Effect of conjugated linoleic acid on heat stressed Brown Swiss and Holstein cattle. J. Dairy Sci. 88:1732-1740.

NRC. 2001. Nutrient Requirements of Dairy Cattle. 7th rev. ed. Natl. Acad. Press, Washington, DC.

Petit, H. V., M. Ivan, and P. S. Mir. 2005. Effects of flaxseed on protein requirements and $\mathrm{N}$ excretion of dairy cows fed diets with two protein concentrations. J. Dairy Sci. 88:1755-1764.

SAS Institute. 1999. SAS User's Guide. Statistics. Version 8.1 ed. SAS Institute Inc., Cary, NC.

Shapiro, S. S., and M. Wilk. 1965. An analysis of variance test for normality. Biometrika 52:591-601.

Sukhija, P. S., and D. L. Palmquist. 1988. Rapid method for determination of total fatty acid content and composition of feedstuffs and feces. J. Agric. Food Chem. 36:1202-1206.

Thompson-Crispi, K. A., B. Hine, M. Quinton, F. Miglior, and B. A. Mallard. 2012. Short communication: Association of disease incidence and adaptive immune response in Holstein dairy cows. J. Dairy Sci. 95:3888-3893.

Van Soest, P. J. 1963a. Use of detergents in the analysis of fibrous feeds. I. Preparation of fiber residues of low nitrogen content. J. Assoc. Off. Anal. Chem. 46:825-829.

Van Soest, P. J. 1963b. Use of detergents in the analysis of fibrous feeds. II. A rapid method for the determination of fiber and lignin. J. Assoc. Off. Anal. Chem. 46:829-835.

West, J. W. 1999. Nutritional strategies for managing the heat-stressed dairy cow. J. Dairy Sci. 82:21-35.

West, J. W. 2003. Effects of heat-stress on production in dairy cattle. J. Dairy Sci. 86:2131-2144.

Yaqoob, P., and P. C. Calder. 1998. Cytokine production by human peripheral blood mononuclear cells: Differential sensitivity to glutamine availability. Cytokine 10:790-794.

Yeh, C. L., C. Hsu, S. Yeh, and W. Chen. 2005. Dietary glutamine supplementation modulates Th1/Th2 cytokine and interleukin-6 expressions in septic mice. Cytokine 31:329-334. 